\title{
PENGARUH RELATIONSHIP MARKETING TERHADAP CUSTOMER LOYALTY DAN CUSTOMER SATISFACTION SEBAGAI VARIABEL INTERVENING PADA PT. FUBORU INDONESIA DI SURABAYA
}

\author{
Clarisha Octavia Widjaja. \\ Praktisi Pemasaran di Surabaya \\ E-mail: Clarisha_o@yahoo.com
}

\begin{abstract}
Abstrak: Tujuan dari penelitian ini adalah untuk menganalisis dampak dari Pemasaran Relasional dengan Loyalitas Pelanggan dan mempertimbangkan faktor-faktor Kepuasan Pelanggan. Penelitian ini kausal dengan menggunakan pendekatan kuantitatif. Pengumpulan data dengan cara terstruktur dan menggunakan metode statistik sebagai analisis data. Metode yang digunakan adalah metode survei yang membuka kuesioner terstruktur. Penelitian ini dilakukan dengan menyebarkan 100 kuesioner kepada pelanggan PT. Fuboru Indonesia. Analisis kuantitatif dengan metode analisis jalur akan menjadi metode teknik untuk menganalisis ini hasil riset. Penelitian ini menunjukkan bahwa kepuasan pelanggan tidak bisa menjadi mediator variabel intervensi antara pemasaran relational dan loyalitas pelanggan.
\end{abstract}

Kata kunci: Pemasaran relasional, loyalitas pelanggan, kepuasan pelanggan

\begin{abstract}
The purpose of this research is to analyze the impact of the Relationship Marketing to Customer Loyalty and consider factors Customer Satisfaction. This study is causally using a quantitative approach. The collection of data in a structured way and using statistical methods as the analysis of data. The method used is a survey method that opens a structured questionnaire. This research conducted by spreading 100 questionnaires to customers of PT Fuboru Indonesia. Analysis quantitative with path analysis method will be the technique method to analyze this research.Tthe results of this study indicates that the customer satisfaction cannot be a mediator of variable intervening between relationship marketing and customer loyalty.
\end{abstract}

Keywords: Relationship marketing, customer loyalty, customer satisfaction.

\section{PENDAHULUAN}

Kendaraan roda dua atau sepeda motor telah berubah menjadi bagian yang penting di masyarakat dan menjadi salah satu alat transportasi utama bagi sebagian besar masyarakat Indonesia. Salah satu cara merawat motor ialah mengecek suku cadang motor dan menggantinya apabila terdapat suku cadang yang sudah tidak layak untuk digunakan agar motor dapat bekerja secara optimal dan perjalanan menjadi lebih aman dan nyaman.

Di tengah persaingan dalam produksi suku cadang yang semakin ketat ini, produsen suku cadang motor berusaha memberikan pelayanan yang terbaik dan juga berbagai cara untuk memasarkan usaha mereka tersebut. Hal ini dilakukan untuk dapat meraih pelanggan dan semakin dikenal oleh masyarakat. Relationship marketing merupakan strategi yang banyak diterapkan oleh perusahaan-perusahaan untuk memperoleh loyalitas dari para pelanggannya yang berupa toko maupun bengkel. Memiliki relationship marketing yang baik dengan pelanggan akan menimbulkan loyalitas dan menciptakan pembelian berulang (Wright, 2004).

Relationship marketing diaplikasikan perusahaan sebagai salah satu upaya untuk mempertahankan diri dalam dinamika bisnis.Ikatan hubungan secara luas dianggap sebagai alat untuk menjaga loyalitas pelanggan. Pada hakekatnya relationship marketing terdiri dari tiga pendekatan yaitu: ikatan keuangan, ikatan sosial, dan ikatan structural (Shammout, Polonsky, \& Edwardson, 2007).

Relationship Marketing merupakan suatu hubungan dalam perusahaan untuk membangun dan mempertahankan pelanggan yang menguntungkan bagi perusahaan (Zeithaml, Bitner, \& Gremler, 2009). Diketahui bahwa ikatan hubungan yang kuat dapat menciptakan kepuasan pelanggan, jika kepuasan yang dirasakan terus-menerus dalam jangka lama akan menumbuhkan loyalitas pelanggan terhadap suatu perusahaan.

Memelihara dan megelola hubungan dengan pelanggan telah muncul sebagai strategi prioritas dalam sebagian besar perusahaan.Karena, pelanggan yang loyal merupakan pelanggan yang menguntungkan. Perusahaan yang berhasil dalam mengembangkan hubungan yang kuat dengan pelanggan akan mendapatkan banak keuntungan dalam jangka yang panjang karena akan sulit bagi kompetitor untuk menggantikan posisi perusahaan yang telah terletak di hati pelanggan. (D. Hutt \& W. Speh, 2013). 
Berdasarkan uraian latar belakang di atas, maka permasalahan yang ditimbulkan adalah:

1. Apakah relationship marketing berpengaruh terhadap customer satisfaction di PT. Fuboru Indonesia di Surabaya?

2. Apakah relationship marketing berpengaruh terhadap customer loyalty di PT. Fuboru Indonesia di Surabaya?

3. Apakah customer satisfaction berpengaruh terhadap customer loyalty di PT. Fuboru Indonesia di Surabaya?

\section{TINJAUAN PUSTAKA}

\section{Relationship Marketing}

Customer relationship marketing menurut (Gummesson, 2004) menjelaskan bahwa keberhasilan dalam relationship marketing merupakan hasil dari seluruh pihak yang berdampak pada perusahaan tersebut, begitu juga dengan pelanggan. Melakukan penawaran atas produk dan memberikan layanan yang terbaik merupakan keinginan terbesar dari pelanggan. Pelanggan mulai menilai kondisi relationship marketing dimulai dari awal, sejak perusahaan memberikan service dan pengiriman barang. Dapat dikatakan bahwa relationship yang baik dengan pelanggan menunjukan kualitas hubungan perusahaan yang baik.

Menurut pendapat (Kotler \& Keller, 2006), (Shammout et al., 2007), (Zeithaml et al., 2009), dan (D.Hutt \& W.Speh, 2013) terdapat 3 pendekatan yang dapat dikembangkan perusahaan dalam memelihara hubungan dengan pelanggan, yaitu:

1) Financial Ties

Pendekatan yang pertama dalam membangun hubungan dengan pelanggan adalah financial ties yang merupakan penghematan ekonomis bagi pelanggan berupa pemberian discount khusus, hadiah, dan lainnya.

2) Social Ties

Social ties mengarah pada kebutuhan dan keinginan pelanggan secara lebih personal. Di tingkat ini, hubungan dengan pelanggan tidak hanya karena insentif harga yang diberikan oleh perusahaan, namun ada ikatan sosial bahkan persahabatan baik antar perusahaan dengan pelanggan, maupun antar pelanggan satu dengan pelanggan yang lainnya serta mempertahankan rasa emosional pembeli dan penjual.

3) Structural Ties

Structural ties timbul karena perasaan aman atau perasaan nyaman pelanggan terhadap badan usaha. Jika pelanggan merasa tidak nyaman dalam berhubungan dengan perusahaan, maka pelanggan dapat meninggalkan perusahaan tersebut dan akan beralih ke pesaing.

\section{Customer Satisfaction}

Customer satisfaction merupakan hasil evaluasi antara kebutuhan dan harapan pelanggan dengan kinerja perusahaan yang telah dirasakan oleh pelanggan. Kepuasan pelanggan dapat didefinisikan oleh (Arnould, Price, \& Zinkhan, 2004; Zeithaml et al., 2009) mengenai perilaku pelanggan purna beli terhadap suatu barang atau jasa yang dirasakan oleh pelanggan. Kepuasan pelanggan hanya dapat diraskan oleh pelangan itu sendiri tergantung pada persepsi dan harapan pelanggan.

Tujuan penting customer satisfaction adalah untuk meningkatkan customer retention (Fornell, 1992). Kepuasan pelanggan yang tinggi dapat berpengaruh pada peningkatan retensi bagi pelanggan perusahaan yang sudah ada. Hal tersebut menjelaskan akan adanya banyak pelanggan akan melakukan pembelian ulang di masa yang akan datang. Berdasarkan dimensi menurut (Arnould et al., 2004) dan (Zeithaml et al., 2009), peneliti melihat dalam perusahaan yang bergerak dalam industri otomotif menggunakan 3 dimensi. Ke tiga dimensi itu adalah:

1) Satisfaction as fulfillment.

Pelanggan akan merasa puas apabila kebutuhan mereka tercukupi atau terpenuhi. Namun kecenderungan pelanggan akan lebih bersifat acuh dan menjadikan respon pelanggan yang pasif.

2) Satisfaction as pleasure.

Pelanggan merasa sangat senang dapat bertransaksi dengan perusahaan.Seluruh kebutuhannya tercukupi dan sangat memuaskan pelanggan.

3) Satisfaction as ambivalene.

Pelanggan dapat saja memiliki pengalaman yang unik terhadap suatu perusahaan. Pengalaman yang unik tersebut menciptakan suatu kepuasan yang terbentuk karena mix feeling.

\section{Customer Loyalty}

Customer loyalty merupakan suatu kesetiaan pelanggan. Menurut (Kotler \& Keller, 2006) dalam membangun customer loyalty perusahaan dapat menggunakan e-mail, situs web, telephone, database, dan perangkat lainnya untuk mendorong terjadinya hubungan dengan pelanggan secara terus-menerus. Customer loyalty adalah komitmen pelanggan yang mendalam dalam melakukan pembelian ulang di 
masa depan (Arnould et al., 2004).Menurut (Tideswell, 2005), (Deng, Lu, Wei, \& Zhang, 2010) terdapat 4 dimensi dalam mengukur customer loyalty, diantaranya adalah:

1) Word of Mouth Promotion

Word of mouth adalah percakapan dari orang ke orang, tertulis, atau komunikasi melalui elektronik atau yang berhubungan dengan manfaat atau pengalaman membeli menggunakan barang/jasa.

2) Future Repurchase Intention

Minat beli merupakan sebuah perilaku pelanggan dimana pelanggan mempunyai keinginan dalam membeli atau memilih suatu produk berdasarkan pengalaman dalam memilih, menggunakan dan mengkonsumsi atau bahkan menginginkan suatu produk/jasa.

3) Price Sensitive

Tingkat sensitif harga diwujudkan dalam bentuk pelanggan akan tetap memilih perusahaan tersebut meskipun harga yang ditawarkan lebih mahal dari perusahaan yang lain selama perusahaan tersebut memberikan manfaat yang lebih baik dari perusahaan lain.

\section{Kerangka Konseptual}

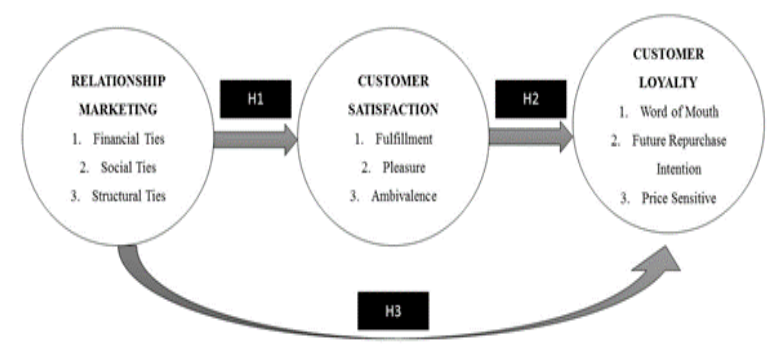

Gambar 1. Kerangka Konseptual

\section{Hipotesis}

Berdasarkan pengamatan di lapangan dan studi literatur maka dirumuskan hipotesis sebagai berikut:

H1: Terdapat pengaruh positif relationship marketing berpengaruh terhadap customer satisfaction pada perushaan PT. Fuboru Indonesia di Surabaya.

$\mathrm{H} 2$ : Terdapat pengaruh positif customer satisfaction berpengaruh terhadap customer loyalty di PT. Fuboru Indonesia di Surabaya.

H3: Terdapat pengaruh positif Apakah relationship marketing berpengaruh terhadap customer loyalty di PT. Fuboru Indonesia di Surabaya.

\section{METODE PENELITIAN}

\section{Populasi dan Sampel}

Populasi adalah wilayah generalisasi yang terdiri dari obyek atau subyek yang dimana mempunyai kualitas dan karakteristik tertentu yang diterapkan oleh peneliti untuk dipelajari dan kemudian ditarik kesimpulannya.Populasi dalam penelitian ini adalah pelanggan toko maupun bengkel dari PT. Fuboru Indonesia di Surabaya.

Teknik pengambilan sampel pada penelitian ini menggunakan teknik non probability sampling, dimana semua populasi tidak memiliki peluang yang sama untuk menjadi responden dan pengambilan sampel didasarkan pada pertimbangan peneliti (Churchill, 2005; Wahdi, 2011). Jenis non probability sampling yang digunakan dalam penelitian ini adalah purposive sampling dimana peneliti melakukan penilaian untuk memilih anggota populasi yang merupakan pelanggan PT. Fuboru Indonesia yang berdomisili di Surabaya dan yang telah melakukan transaksi pembelian dalam waktu 1 tahun atau lebih.

Penelitian ini menggunakan sampel sebanyak 100 responden, dengan berdasarkan pada pertimbangan tingkat keyakinan 0.95 dengan $\alpha \quad 0,05$ dan kesalahan yang mungkin terjadi tidak lebih dari $10 \%$.

\section{Devinisi Operasional Variabel}

Definisi operasional variabel yang akan digunakan dalam penelitian ini terdiri dari 3 variabel, yaitu:

- Variabel eksogen/independen, yaitu Relationship Marketing (X 1) dengan dimensi:

$\mathrm{X} 11=$ Financial Ties

Merupakan penghematan ekonomis bagi pelanggan berupa pemberian discount khusus, hadiah, dan lainnya

$\mathrm{X} 12=$ Social Ties

Merupakan ikatan social, persahabatan antara PT. Fuboru Indonesia dengan pelanggan.Ikatan social digambarkan sebagai hubungan mempertahankan rasa emosional antara PT. Fuboru Indonesia dan pelanggan.

$\mathrm{X} 13=$ Structural Ties

Merupakan pendekatan untuk membangun hubungan yang lebih kuat dengan pelanggan. Pelanggan merasa menjadi bagian dari PT. Fuboru Indonesia.

- Variabel Intervening yaitu, Customer Satisfaction (Y) dengan dimensi, sebagai berikut:

Y11= Fulfillment 
Fulfillment merupakan pemenuhan kebutuhan pelanggan dalam mencapai suatu kepuasan.

$\mathrm{Y} 12=$ Pleasure

Pleasure menunjukan hubungan yang positif antara PT. Fuboru Indonesia dengan pelanggan.

$\mathrm{Y} 13=$ Ambivalence

Ambivalance merupakan perasaan unik yang dirasakan pelanggan saat bertransaksi dengan PT. Fuboru Indonesia.

- Variabel Endogen (Z) yaitu Customer Loyalty, dengan dimensi:

$\mathrm{Z} 11=$ Word Of Mouth

Merupakan percakapan dari mulut ke mulut yang memiliki manfaat atau pengalaman dalam barang atau jasa.

Z12 = Future Repurchase Intention Merupakan perilaku pelanggan yang mempunyai keinginan untuk membeli dan memilih kembali suatu produk atau jasa.

Z13 = Price Sensitive

Merupakan perwujudan bentuk pelanggan akan tetap memilih perusahaan tersebut meskipun harga yang ditawarkan lebih mahal dari perusahaan lainnya selama perusahaan memberikan manfaat yang lebih baik dari perusahaan lain.

\section{Teknik Analisa Data}

Pengujian hipotesis pada penelitian ini dilakukan dengan menggunakan teknik path analysis. Teknik path analysis di kembangkan oleh Sewal Wright pada tahun 1934. Pengujian statistik pada model path analysis dalam penelitian ini dilakukan dengan menggunakan metode partial least square regression. Pengolahan data menggunakan program smart PLS.

\section{HASIL PENELITIAN DAN PEMBAHASAN}

Evaluasi Path Coefficient dan Coefficient of Determination (R2)

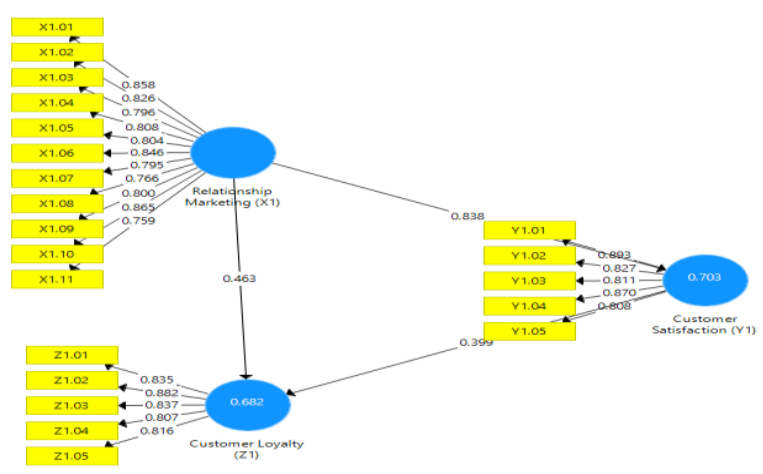

Gambar 2. Path Coefficient dan Coefficient of Determination
Pada analisa path coefficient ini telah terbukti bahwa customer satisfaction merupakan variable intervening yang dimana tidak memperkuat hubungan antara relationship marketing dengan customer loyalty sebesar 0.335 yang dimana merupakan hasil perkalian antara 0.838 dan 0.399 .

Gambar diatas merupakan bukti bahwa dalam penelitian ini customer satisfaction tidak memperkuat hubungan antara variable independen terhadap variable dependen.Melainkan hubungan secara langsung antara variable independen ke variable dependen lebih kuat.

Selain itu, keseluruhan variable dalam model ini memiliki path coefficient dengan angka yang positif. Sehingga jika semakin besar nilai path coefficient pada satu variable independen terhadap variable dependen tersebut, maka semakin kuat juga pengaruh antara variable independen terhadap variable dependen tersebut.

Nilai coefficient of determination $\left(\mathrm{R}^{2}\right)$ yang di dalam gambar ditunjukan pada angka di dalam lingkaran customer satisfaction yang dipengaruhi oleh relationship marketing sebesar 0.703 . Lalu variable customer loyalty yang dipengaruhi oleh relationship marketing sebesar 0.682 .

\section{T-Statistic}

\begin{tabular}{|c|c|c|c|c|}
\hline & $\begin{array}{l}\text { Original } \\
\text { Sample } \\
(\mathrm{O})\end{array}$ & $\begin{array}{c}\text { Sample } \\
\text { Mean } \\
\text { (M) }\end{array}$ & $\begin{array}{l}\text { Standard } \\
\text { Deviation } \\
\text { (STDEV) }\end{array}$ & $\begin{array}{c}\text { T Statistics } \\
(|\mathrm{O} / \mathrm{STDEV}|)\end{array}$ \\
\hline $\begin{array}{l}\text { Customer } \\
\text { Satisfaction } \\
\text { (Y1) } \rightarrow \\
\text { Customer } \\
\text { Loyalty } \\
\text { (Z1) }\end{array}$ & 0.398579 & 0.393017 & 0.116969 & 3.407566 \\
\hline $\begin{array}{l}\text { Relationship } \\
\text { Marketing } \\
(\mathrm{X} 1) \rightarrow \\
\text { Customer } \\
\text { Loyalty } \\
(\mathrm{Z1})\end{array}$ & 0.462602 & 0.465673 & 0.122134 & 3.787662 \\
\hline $\begin{array}{l}\text { Relationship } \\
\text { Marketing } \\
(\mathrm{X} 1) \rightarrow \\
\text { Customer } \\
\text { Satisfaction } \\
\text { (Y1) }\end{array}$ & 0.838187 & 0.833151 & 0.042507 & 19.718964 \\
\hline
\end{tabular}

T-statistic pada pengaruh customer satisfaction terhadap customer loyalty menunjukan 3.407566 yang artinya customer satisfaction berpengaruh signifikan terhadap customer loyalty.T-statistic pada pengaruh relationship marketing terhadap customer loyalty menunjukan 3.787662 yang artinya customer 
satisfaction berpengaruh signifikan terhadap customer loyalty. T-statistic pada pengaruh relationship marketing terhadap customer satisfaction menunjukan 19.718964 yang artinya relationship marketing berpengaruh signifikan terhadap customer satisfaction.

\section{Uji Hipotesis}

\begin{tabular}{|c|c|c|}
\hline Hipotesis & Keterangan & $T$-statistic \\
\hline $\mathrm{H}_{1}$ & $\begin{array}{l}\text { Terdapat pengaruh signifikan } \\
\text { dari customer satisfaction } \\
\text { terhadap customer loyalty }\end{array}$ & 3.407566 \\
\hline $\mathrm{H}_{2}$ & $\begin{array}{l}\text { Terdapat pengaruh signifikan } \\
\text { dari Terdapat pengaruh } \\
\text { signifikan dari relationship } \\
\text { marketing terhadap customer } \\
\text { loyalty }\end{array}$ & 3.787662 \\
\hline $\mathrm{H}_{3}$ & $\begin{array}{l}\text { Terdapat pengaruh signifikan } \\
\text { dari Terdapat pengaruh } \\
\text { signifikan dari relationship } \\
\text { marketing terhadap customer } \\
\text { satisfaction }\end{array}$ & 19.718964 \\
\hline
\end{tabular}

Pengaruh antar variabel dikatakan bersifat signifikan apabila nilai T-statistics lebih besar dari angka 1,96. Sehingga diketahui berdasarkan tabel 6 customer satisfaction berpengaruh signifikan terhadap customer loyalty, relationship marketingberpengaruh signifikan terhadap customer loyalty danrelationship marketing berpengaruh signifikan terhadap customer satisfaction.

\section{Pembahasan}

\section{Relationship Marketing terhadap Customer Satis-} faction

Penelitian ini memiliki hasil bahwa relationship marketing PT. Fuboru Indonesia memiliki pengaruh terhadap customer satisfaction secara signifikan dengan nilai uji $T$-statistic $>1.96$ yaitu 19.718964 .

Penelitian ini mempunyai hasil yang menunjukkan bahwa relationship marketing berpengaruh signifikan terhadap customer satisfaction yang dimana hal ini sesuai dengan pendapat (Lo Chung, 2012; Mohammad Al-Hersh, Suleiman Aburoub, \& Saaty, 2014) bahwa dalam membangun relationship dalam mengambil hati para pelanggan, perusahaan harus dapat meningkatkan customer satisfaction.

PT. Fuboru Indonesia telah membangun berbagai macam relasi dengan pelanggan yang merupakan toko maupun bengkel. Terutama dari segi pemberian kemudahan dan bonus-bonus kepada pelanggan lewat pendekatan finansial, social, dan structural. Dalam analisa deskriptif dimensi variablevariabel juga menunjukan kesetujuan pelanggan akan berbagai macam bentuk relationship yang terjalin dan begitu juga kesetujuan pelanggan terhadap satisfaction yang telah dirasakan oleh pelanggan.

\section{Relationship Marketing terhadap Customer Loyalty}

Penelitian ini mempunyai hasil yang menunjukkan bahwa relationship marketing berpengaruh signifikan terhadap customer loyalty yang dimana hal ini sesuai dengan pendapat (Sirdeshmukh, Singh, \& Sabol, 2002; Zeithaml, Berry, \& Parasuraman, 1996) bahwa relationship marketing akan meningkatkan customer loyalty karena kesetiaan pelanggan akan tercipta saat perusahaan memberikan banyak kontribusi yang diinginkan pelanggan.

PT. Fuboru Indonesia berupaya dalam meningkatkan kesetiaan pelanggan dalam berbagai hal. Dalam relationship marketing yang diciptakan oleh PT. Fuboru Indonesia untuk mengikat kesetiaan pelanggan adalah memperlakukan pelanggan dengan baik, selain itu memberikan kontrak jangka panjang yang menguntungkan untuk kedua belah pihak dan pastinya dalam relationship marketing PT. Fuboru Indonesia yang baik akan menimbulkan customer loyalty dengan kesediaan pelanggan melakukan word of mouth, pembelian ulang, dan tidak terlalu peka terhadap harga produk PT. Fuboru Indonesia yang dapat berubah.

\section{Customer Satisfaction terhadap Customer Loyalty}

Penelitian ini mempunyai hasil yang menunjukkan bahwa customer satisfaction berpengaruh signifikan terhadap customer loyalty yang dimana hal ini sesuai dengan pendapat (Mohammad Al-Hersh et al., 2014) diamana kepuasan pelanggan akan selalu dapat meningkatkan hubungan secara jangka panjang dengan perusahaan. Dapat dikatakan bahwa dengan memberikan kepuasan pelanggan maka dengan sendirinya pelanggan akanmerasa setia dan loyal terhadap perusahaan.

Seperti PT. Fuboru Indonesia yang memberikan kepuasan terhadap pelanggan dengan memberikan retur atas produk toko maupun bengkel dengan memberika retur, menerima complain dan menanganinya dengan baik maka pelanggan akan merasa puas terhadap PT. Fuboru Indonesia sesuai dengan hasil dari kuisioner yang telah disebar dan berdasarkan analisa deskriptif dimensi customer satisfaction dan loyalty menunjukan kesetujuan pelanggan akan terciptanya customer satisfaction dan customer loyalty PT. Fuboru Indonesia. 
Variabel Customer Satisfaction Tidak Memediasi Hubungan Relationship Marketing Terhadap Customer Loyalty.

Penelitian ini bertujuan untuk melihat pengaruh relationship marketing terhadap customer loyalty dengan menggunakan customer satisfaction sebagai variable intervening.Customer satisfaction memiliki hubungan yang kuat terhadap relationship marketing dan customer loyalty. Namun dalam PT. Fuboru Indonesia hubungan antara relationship marketing dan customer loyalty secara langsung lebih kuat.

Hubungan relationship marketing dan customer loyalty ini lebih kuat karena dalam PT. Fuboru Indonesia karena tujuan utama relationship marketing PT.Fuboru Indonesiasebenarnya adalah untuk menemukan lifetime value yang merupakan kesetiaan dari pelanggan. Setelah lifetime value didapat, tujuan selanjutnya adalah bagaimana agar lifetime value masing-masing kelompok pelanggan dapat terus diperbesar dari tahun ketahun.Setelah itu, tujuan ketiganya adalah bagaimana menggunakan profit yang didapat dari dua tujuan pertama untuk mendapatkan pelanggan baru dengan biaya yang relatif murah. Dengan demikian, tujuan jangka panjangnya adalah menghasilkan keuntungan terus menerus dari dua kelompok pelanggan yang merupakan pelanggan yang sekarang dan pelanggan baru (Chan, 2003).

\section{KESIMPULAN DAN SARAN}

\section{Kesimpulan}

Penelitian diatas dapat dilihat bahwa variable variabel tersebut memiliki pengaruh antara satu variable dengan variable lainnya. Relationship marketing terhadap customer satisfaction, relationship marketing terhadap customer loyalty dan customer satisfaction terhadap customer loyalty.

Seluruh variable ini menunjukan suatu pengaruh, namun berdasarkan path coefficient menunjukkan bahwa dalam penelitian ini customer satisfaction tidak memperkuat hubungan antara variable independen yang merupakan relationship marketing terhadap variable dependen yang merupakan customer loyalty. Melainkan hubungan secara langsung antara variable independen ke variable dependen lebih kuat.

\section{Saran}

PT. Fuboru Indonesia dapat mengerti ekspektasi pelanggan dengan berbagai cara sebagai berikut: PT. Fuboru Indonesia memberikan tugas tambahan kepada para sales selain menjual produk, menjelaskan produk, dan mengecek barang di toko, sales diharuskan untuk memberi laporan mengenai harapan pelanggan dan informasi sebanyak-banyaknya mengenai pelanggan terhadap PT. Fuboru Indonesia.

Empowering employes dapat dilakukan oleh PT. Fuboru Indonesia dengan cara para sales berhak memberikan loyalty awards berupa tambahan diskon sebesar 3\% dan hadiah Fuboru gift set secara langsung dengan memenuhi syarat-syarat tertentu, seperti pelanggan yang berhak mendapatkan ada pelanggan yang telah menjadi pelanggan aktif PT. Fuboru Indonesia lebih dari 15 tahun dan melakukan pengambilan lebih dari 3 kali sebulan. Dengan cara demikian pelanggan akan merasa menjadi bagian dari PT. Fuboru Indonesia dan tidak memerlukan proses yang sulit.

\section{DAFTAR PUSTAKA}

Arnould, E., Price, L., \& Zinkhan, G. (2004). Consumer 2nd ed. Boston, Massachusetts: The McGraw-Hill Companies.

Chan, S. (2003). Relationship Marketing: Inovasi pemasaran yang membuat pelanggan bertekuk lutut. Jakarta: PT. Gramedia Pustska Utama.

Churchill, G. A. (2005). Dasar-dasar riset pemasaran Jilid 1 Ed.4. Jakarta: Erlangga.

D.Hutt, M., \& W. Speh, T. (2013). Business Marketing Management: B2B, 11th Edition. (Jack W. Calhoun, Ed.) (11th ed.). United States: Cengage Learning.

Deng, Z., Lu, Y., Wei, K.K., \& Zhang, J. (2010). Understanding customer satisfaction and loyalty: An empirical study of mobile instant messages in China. International Journal of Information Management, 30(4), 289-300. https://doi.org/ 10.1016/j.jijinfomgt.2009.10.001

Fornell, C. (1992). Satisfaction Barometer: The Swedish Experience, 56(1), 6-21.

Gummesson, E. (2004). Return on Relationship (ROR): The value of relationship marketing and CRM in business to business contexts. Business \& Industrial Marketing, 19, 136-148.

Kotler, P., \& Keller, K.L. (2006). Manajemen Pemasaran. (J. Purba, Ed.) (12th ed.). New Jersey: prentice hall.

Lo Chung, S. (2012). A study of relationship marketing on customer datisfaction, 8(1), 91-94.

Mohammad Al-Hersh, D.-A., Suleiman Aburoub, ti, \& Saaty, A. S. (2014). The Impact of Customer Relationship Marketing on Customer Satisfaction of the Arab Bank Services. International Journal of Academic Research in Business and Social Sciences, 4(5), 2222-6990. https://doi. org/10.6007/IJARBSS/v4-i5/824 
Shammout, A., Polonsky, M., \& Edwardson, V. (2007). Relational Bonds and Loyalty: The Bonds that Tie, (January 2012). Retrieved from http://anzmac.org/conference_archive/2007/pape rs/AShammout_1.pdf

Sirdeshmukh, D., Singh, J., \& Sabol, B. (2002). Consumer Trust, Value, and Loyalty in Relational Exchange. Journal of Marketing, 66 (January), 15-37. https://doi.org/10.1509/jmkg. 66.1.15.18449

Tideswell, C. (2005). Loyalty Behaviour And Relationship Commitment Towards Hotel Services Carmen Tideswell, Southern Cross University, 80-86.
Wahdi, M. (2011). Riset pemasaran: teori dan aplikasi untuk pengambilan keputusan cet. 1. Jakarta: Caps (Center for Academic Publishing Service).

Wright, R. (2004). Business-to-business Marketing: A Step-by-step Guide (illustrate). London: Pearson Education.

Zeithaml, V.A., Berry, L.L., \& Parasuraman, A. (1996). The Behavioral Consequences of Service Quality. The Journal of Marketing, 60(2), 31-46. https://doi.org/10.2307/1251929

Zeithaml, V.A., Bitner, M.J., \& Gremler, D.D. (2009). Service Marketing: Integrating Customer Focus Across The Firm (McGraw-Hil). New York. 